\title{
Zafer Şenocak’ın “Tehlikeli Akrabalık” Romanında ‘Öteki’
}

\section{'Other' in Zafer Şenocak's “Perilous Kinship” Novel}

\author{
Öğr. Gör. Asuman YAPRAK (iD)1, Doç. Dr. Hasan Kazım KALKAN (D)2
}

\begin{abstract}
$\ddot{O} \mathbf{z}$
Ev sahibi toplum tarafindan yabancı olarak kabul edilen azınlık toplumun, kuşaklar arası kimlik ve yurt arayışı, artan göç sayısı ile sosyal bilimlerde olduğu kadar Edebiyat alanında da sıkça ele alınan konular arasında yer almaktadır. Göç sonucu ortaya çıkan toplumsal ve sosyal sorunlar, bu doğrultuda edebi eserlerin yazılmasına da yol açmıştır. Bu bağlamda Türkiye'den Almanya'ya göç, öteki olarak Türkler (göçmenler) ve kimlik arayışı edebiyata yansımış ve bu yansıma sonucunda yeni bir edebi tür olan göçmen edebiyatı ortaya çıkmıştır. Göçmen yazarlar, Almanya'da yaşayan Türklerin sorunlarını konu alan eserleri ile göçmenlerin sesi olmuş ve öteki olarak sürdürdükleri hayatlarını Dünya'ya duyurmuştur. Özellikle "biz" ve "öteki"”nin inşa edilmesindeki toplumsal pratikler, Zafer Şenocak gibi bu edebiyat türünün yazarlarının eserlerinde işlenen motifler arasında yer almıştır. Önceki çalışmalarda daha çok kimlik ve yurt arayışı üzerinden incelenen Zafer Şenocak'ın "Tehlikeli Akrabalık" romanı, bu çalışmada "biz" i tanımlamak için ortaya çıkan "öteki" motifi temelinde ele alınmıştır. Ötekinin anlaşılmasına katkıda bulunmak için klasik bakış açısından ziyade etnik temelli, medeniyet temelli, ekonomik temelli ve dinsel temelli sınıflandırılmalar yapılmıştır. Bu sınıflandırmalar sonucunda etnik bilincin uyanmasıyla etnik köken en sık ötekileştirme aracı olarak başvurulan 'öteki'lerden biri olduğu anlaşılmıştır. Ayrıca Oryantalist bakış açısı ile Batının üstün ve ideal, Doğunun ise geri kalmış bir medeniyet olarak tasvir edildiği görülmüştür. Güçsüz ve yoksulun, ayrıca kendi dinine mensup olmayan kişilerin de ötekileştirildiği, yapılan inceleme sonucunda anlaşılmıştır.
\end{abstract}

Anahtar Kelimeler: Öteki, göçmen edebiyatı, Zafer Şenocak, kimlik

Makale Türü: Araştırma

\begin{abstract}
The search for an intergenerational identity and homeland of the minority society, which is regarded as a foreigner by the host society, is among the subjects that are frequently discussed in the field of literature as well as in the social sciences with the increasing number of migration. Social problems that arose as a result of migration have been reflected in literary works inevitably. As a part of this migration process, migration from Turkey to Germany, Turks as "others" (migrants) and the search for identity have become the focus of literary works. As a result of this effect, a new literary genre came out under the umbrella of migrant literature. With their works reflecting the problems of Turks living in Germany, immigrant writers have become the voice of immigrants and have announced their lives as "the other" to the world. Social practices in the construction of "us" and "others", the themes around the sense of belonging and identity issues are the main motives of writers like Zafer Senocak who is considered in this new genre. This study aims to analyze Senocak's "Perilous kinship" through "others" perspective different from previous studies on the novel through the search for identity and homeland. With this aim, the novel has been analyzed focusing on the "others" rather than the identity. To serve the understanding of the others, a new classification has been applied: ethic, civilization, economic and religious. As a result of this classification, with the awakening of ethnic consciousness, it is understood that ethnic origin is the most frequently used one as a means of marginalization. In addition, it is seen that the West was depicted as a superior and ideal, and the East as a backward civilization with an Orientalist perspective. Another result
\end{abstract}

\footnotetext{
${ }^{1}$ Kastamonu Üniversitesi, Yabancı Diller Yüksekokulu, ayaprak@kastamonu.edu.tr

${ }^{2}$ Gazi Üniversitesi, Gazi Eğitim Fakültesi, Alman Dili Eğitimi, k.kalkan@gazi.edu.tr 
of the study shows that the weak and the poor, as well as those who do not belong to their religion, are those who have been marginalized.

Keywords: Other, migrant literature, Zafer Senocak, identity

Paper Type: Research

\section{Giriş}

Kimlik var olduğundan beri öteki ve ötekileştirme de var olmuştur. Bir başka deyişle 'öteki' 'ben'in veya 'biz'in ayrılmaz bir parçasıdır. Bizim kim ya da ne olduğumuzu belirleyen en önemli unsur bizim dışımızdaki, yani 'öteki'dir. Medeniyet, din ya da etnisite gibi kapsama alanı çok geniş kavramlar üzerinden düşünüldüğünde; 'öteki' veya 'biz' olma durumu, kişisel tercihlerden ziyade bireyin içinde doğup büyüdüğü şartların şekillendirdiği bir olgudur ve birçok insan için sorun teşkil etmez. Ama 'öteki' lik yalnızca kimlik belirleyici bir öge olmaktan çıkıp ayrımcılığa sebebiyet veren bir unsura dönüştüğünde sorunları da beraberinde getirir. Farklı kültüre sahip bir topluluğun içerisinde azınlık olarak yaşamak zorunda kalan bireyler ‘öteki' olma durumu kaynaklı ayrımcılığı en çok hissedenlerdir.

Bu çalışmada ele alınmış olan Tehlikeli Akrabalık isimli romanın yazarı Zafer Şenocak da Almanya'da yaşayan ve kendi deneyimlediği ‘öteki’ olma durumunu birçok kez romanlarına yansıtmış bir yazardır. Tehlikeli Akrabalık romanının merkezinde "Kültürlerarası edebiyatın en çok işlediği konuların başında gelen aidiyet ve kimlik sorunu" (Kalkan, 2018, s. 66) yer almaktadır. Bu soruna yol açan en önemli olgu ise roman kahramanının toplum tarafından maruz bırakıldığı 'öteki'leştirmedir. İlgili eserin 'öteki' bakımından tercih edilmesinin nedeni, romanın ana karakteri Sascha Muhteschem'in üç farklı etnik kökene sahip (Türk, Alman ve Yahudi) bir kişilik olmasında yatmaktadır. Sascha, bulunduğu yere ve duruma göre 'öteki' konumunda değerlendirilebilecek üç farklı kimliği tek bir kişide barındıran bir karakterdir ve bu haliyle edebiyatta 'öteki' liğin ele alınışı bakımından oldukça ilginç bir figürdür.

\section{Yöntem}

Bu çalışmada kimlik oluşturabilmek için bir "öteki”ye ihtiyaç duyulduğu göz önünde bulundurularak medeniyet, etnik, dinsel ve ekonomik temelli nedenlerle ortaya çıkan 'öteki' ortaya konmaya çalışılmıştır. Bu amaçla metindeki öteki incelemesi hem metin odaklı hem de dönemin özellikleri üzerinden metin incelemesi yöntemi ile yapılacaktır. 'Öteki'nin anlaşılmasının ardından romandaki ötekileştirmeler etnik temelli, medeniyet temelli, ekonomik temelli ve dinsel temelli olarak sinıflandırılarak incelenecektir.

\section{2. 'Öteki'}

Öteki kavramının kelime anlamı bakımından açıklanmasına geçilmeden önce 'öteki'ye neden ihtiyaç duyulduğunun anlaşılması, ötekinin ortaya çıkışına 1şık tutacaktır. 'Öteki', insanın sosyokültürel gelişiminde en önemli dayanak noktalarından biri ve en temel ihtiyacı olan kimlik inşasının temelidir. Kimlik temel sözlük anlamıyla "toplumsal varlık olarak insanın nasıl bir kimse olduğunu gösteren belirti, nitelik veya özelliklerin bütünü” olarak tanımlanmaktadır (TDK, 2020).

Almancada ise kimlik kavramı Latince kökenli idem'den türeyen Identität sözcügü ile karşılanmaktadır. Burada idem ise das Selbe (aynı) anlamını taşımaktadır. Yani insan kendi kimliğini kurarak aslında kendine benzeyenlerin arasında kendine bir yer edinmeyi amaçlamaktadır. Bu doğrultuda Heiddeger, Selbigkeit (Aynısallık) kavramını birlik duygusu olarak açıklamakta ve kimliği grup içinde oluşan bir karakteristik oluşum olarak tanımlamaktadır (Heidegger, 2006, s. 33-36). Burada idem kelimesi de göz önünde bulundurulunca insanların 'aynı' oldukları takdirde kimlikten bahsedilebileceği anlaşılabilir. Diğer bir ifadeyle kimlik edinimi, bireyin kendisine ötekinin gözünden bakarak tanımlamasıdır 
(Mead'den aktaran Abels, 2006, s. 250). Bu noktada 'öteki'nin dışlanması benlik imajının temel yapısına girmiştir. Benliği farklı olarak tasvir etmek için 'öteki'nin 'öteki' olarak kabul edilmesi ve sınırlarının çizilmesi gerekmektedir (Assmann, 1994, s. 20; Supper, 1999, s. 34). Bu durumda bireyler ve topluluklar kendilerini tanımlayabilmek ve bir kimlik oluşturabilmek için bir 'öteki'ye ihtiyaç duymaktadır. Kendilerinden olmayanın, kendilerine benzemeyenin belirlenmesi bir toplumun 'biz’ kimliğinin oluşmasını mümkün kılmaktadır.

'Öteki' kavramının Türk Dil Kurumu Sözlüğünde belirtilen tanımına bakıldığında "Diğeri öbürü; Sözü edilen veya benzer iki nesneden önem ve konum bakımından uzakta olan; Mevcut kültürün içinde dışlanmış olan" anlamlarını taşıdığı görülmektedir (TDK, 2020). Bu tanımdan yola çıkarak birey veya toplumlar kendi gibi olmayan veya kendinden olmayan kişilere, gruplara veya toplumlara kötü özellikler taşıyan 'öteki' sıfatını yüklemekte ve onu dışarıda tutma eğilimi göstermektedir (Akpınar ve Şahin, 2017, s. 331). Dahası bu sözlük anlamı aslında 'öteki'ye dair temel noktaları vermektedir: Her şeyden önce 'öteki', bizden olmayan öbürüdür, bize uzak olandır, bizden önemsiz olandır, dışlanmış olandır. 'Öteki' "kendi tecrübemizle oluşabileceği gibi duyduklarımız ya da okuduklarımız ile de şekillenebilmektedir” (Perk, 2019, s. 769).

'Biz', 'öteki'ni tanımlarken kendi kültür ölçütlerini kullanmakta ve sınırlarını buna göre çizmektedir (Şengül, 2007, s. 98). Buna göre bizden olmayan, yabancı, kendimizden saymadığımız ve bize uymayan insanlar 'öteki' olarak tanımlanmaktadır (Uygur, 2016, s. 48). İnsanların etraflarına bir sınır çizmesi ile ortaya çıkan 'öteki' bu sınırların dışında bırakılan birey veya toplumlardır. Bu açıdan ötekileştirme çoğu zaman genelleyici bir yaklaşım olmakla birlikte, 'kötü' algılanan aile, cinsiyet, din, etnik köken gibi grup ve toplulukları da öteki'ye dâhil etmektedir (Öz, 2018, s. 129).

Ötekileştirme aynı zamanda saygı eksikliğini de içermektedir. Cinsiyet, ırk ve etnik kökenin dışında insanın insanlığına gösterilmeyen saygı ve haksızlığa uğramış grupların kendilerine özgü inanış veya dünya görüşlerine gösterilmeyen saygı bunlara birer örnektir (Habermas, 2015, s. 113).

Güç ilişkisi açısından bakıldığında sadece egemen grup özelliklerini (kimliklerini) kabul ettirme ve ötekinin özelliklerini aşağılama gücüne sahiptir. Erkeğin ötekisi kadın, beyaz adamın ötekisi siyah adam ise de bunun tersi mümkün değildir (Staszak, 2008, s. 2). Dolayısıyla ezenezilen ilişkisi de ötekileştirme ile alakalı olup ezilen tarafta olan 'öteki' ezenin konumuna geçmek ister ve ezeni rol model olarak alır. Bu ise ezilenin yani 'öteki’nin ezenin özelliklerini almak istemesi ile başlamakta ve başkalarını ötekileştirmesine yol açmaktadır (Akpınar ve Şahin, 2017, s. 333).

Tüm bu sosyo-kültürel ve kimliksel süreçlerin temelinde olan 'öteki' ve ötekileştirme, kültürün aynası olan dilde de karşımıza çıar. Birçok dilde yabancıya kötü özellikler yükleyen atasözleri ve deyimler bulunmaktadır. Örneğin "akarsuya inanma, eloğluna dayanma"; "çalma elin kapısını, çalarlar kapını"; "el için kuyu kazan, evvela kendi düşer"; "çingeneye beylik vermişler, önce babasını asmış (kesmiş)"; "zengin giyerse sağlıcakla, fakir giyerse nerden buldu ki derler" gibi atasözleri yabancının, çeşitli toplulukların ve fakirin ötekileştirilmesinin Türkçeye yansımış halidir (Kurtoğlu Zorlu, 2018, s. 486-493).

Ötekileştirme eylemi bir tarihi süreci kapsamakla birlikte Doğu-Batı mücadeleleri gibi toplumsal ötekileşmelere de dayanabilir. Özellikle Yeni Dünya'nın keşfi ile 'öteki'yi ve bundan dolayı kendini keşfetme ortaya çıkmıştır. Nitekim, Şengül'ün vermiş olduğu örneğe göre "Beyaz adam Kızılderili ile karşılaşmadan önce kendi rengini ne kadar irdelemiş olabilirdi?". $\mathrm{Bu}$ açıdan düşünüldüğünde 'öteki'nin aslında mevcut olanın keşfedilmesi veya idrak edilmesi anlamına da geldiği görülmektedir (Şengül, 2007, s. 98). Yakın döneme gelindiğinde ise Modern Çağda 'öteki'ni uzaklaştırma hatta yok etme bilinci Ulus-Devlet anlayışının ortaya çıkmasına götürülebilir. Bu düşünceyi geliştirenlerden biri olan Habermas'a göre uluslar (Alm. Nationen) siyasi olmayan coğrafi sınırlar içerisinde yerleşim ve komşuluklar ile kültürel 
bağlamda, ortak bir dile, töreye ve devlete ilişkin örgütlenme biçimi çerçevesinde kaynaşmış soy topluluklarıdır. "Natio" sözcük kökü Ortaçağ ve Yeniçağın başlarına dayanmaktadır. Ortaçağ üniversitelerine giden öğrencilerin, geldikleri memleketlere (nationes) göre gruplandırıldıkları görülmektedir. Bu gruplandırmalarla birlikte oluşan milli köken, baştan beri öteki ve yabancı olanın kendisinden farklı olduğu şeklindeki olumsuz dışlamayı da beraberinde getirmiştir. Yabancı olan her şeyden korunma, diğer ulusları değerden düşürme ve azınlıkları (milli, etnik ve dini) -özellikle Yahudi kökenlileri- dışlamak için bir ulusa ait olma geçerli bir araç haline gelmiştir. Avrupa'daki milliyetçilik akımı ile vahim sonuçlar ortaya çıkmış ve bu durum süreç içerisinde Yahudi düşmanlığı ile özdeşleşmiştir (Habermas, 2015, s. 18-19). Ötekileştirmenin diğer yüzünden bakıldığında bir ulusun parçası olma düşüncesi ile o zamana kadar birbirlerine yabancı olan bireyler arasında dayanışmacı bir bağ kurulmuş, birbirlerine yakın olan fakat farklı uluslara mensup olan kişiler arasında ise bir ayrışma ortaya çıkmıştır.

Yine yakın dönemde 19. yüzyılda Batıda ortaya çıkan Oryantalizm (Şarkiyatcılık) kavramı ötekileştirmenin kurumsallaşmış örnekleri arasındadır. Bu teorinin kurucusu olan Edward Said'e göre Avrupa'nın (veya Batı'nın) kendisini Doğu üzerinden zıt fikri, karakteri ve deneyimleri aracılığıyla tanımlaması ötekileştirmenin medeniyet ölçeğinde gerçekleştirilmesidir. Ayrıca Batı'nın Doğu’ya karşı üstünlüğünü hissettirmek ve göstermek için ortaya çıkan bu kavram ve inceleme türü, Doğu'nun Batılı ülkelerden hiçbir zaman üstün olmadığını ve olamayacağını da belirtmektedir (Said, 1978, s. 18-25).

Bir bütün olarak 'Batı', bir bütün olarak 'Doğu'dan ötekileştirme yoluyla ayrılmakta ve bu süreçte kendisini yeniden inşa etmektedir. Bu inşa sürecinde iyi olan tüm özellikler Batı'ya atfedilmekte, kötü olanlar ise 'Doğuya' mal edilmektedir.

Sanat, edebiyat ve siyaset dünyasında ise ötekileştirme ve 'öteki' bazen doğrudan bazen ise imgeler veya benzetmeler ile ifade edilmektedir. 'Öteki'ni simgeleyen veya çağrıştıran objeler kullanılmakta ve böylelikle 'öteki' tasvir edilmektedir (Şengül, 2007, s. 104). Burada ‘öteki' ile bazen milli veya dini bilinci kuvvetlendirmek amaçlanmakta bazen ise altında 1rkçı veya din düşmanı düşünceler yatabilmektedir.

Hem imparatorluk geçmişi hem de modern dönem sonrası sanayileşme ile birlikte yaşadığı göç hareketi gibi nedenlerden dolayı Almanya farklı etnik grupları içerisinde barındıran bir ülkedir. Burada doğal olarak ortaya çıkan 'öteki' ve ötekileştirme, göçmen edebiyatı veya yabancılar edebiyatı olarak adlandırılan, konuk işçilerinin ortaya çıkardığ edebiyat türünde çokça ele alınmaktadır. Başka bir ülkeden gelmiş olmaları, zaten 'öteki' olmaları için yeterli insanların, bunun yanında bir de 1srarla ötekileştirme çabalarına maruz kalmaları göçmen edebiyatına bolca malzeme sağlamıştır. Bu durum edebiyat açısından her ne kadar bir zenginlik olarak addedilse de, toplumsal barış ve huzur açısından çok sayıda olumsuzluğu da beraberinde getirmekte, göçmenlerin kendilerini bir türlü içinde yaşadıkları toplumun bir parçası olarak görememelerine yol açmaktadır.

"Unutulmamalıdır ki, sürekli farklılıklara vurgu yapan birtakım sınıflandırmalara dâhil edilen insanların kendilerini farklı hissetmeleri kaçınılmazdır" (Kalkan, 2018, s. 196).

\section{3. "Tehlikeli Akrabalık" Romanında 'Öteki'}

Ailesi ile 1970 yılında altı yaşındayken Türkiye'den Almanya'ya göç eden Zafer Şenocak, göçmen edebiyatının tanınmış isimlerindendir. Eserleri ile Almanya'da yaşayan Türklerin sesi olmuş, bir anlamda ötekilerin sesini duyurmuş ve eserlerinde bu bağlamda aidiyet ve kimlik sorunlarını konu edinmiştir. Bunun sebebi de bir bakıma yazarın içinde bulunduğu toplum ve toplum kodlarına dair sorgulamalarında yatmaktadır (Er, Koçak, Hertsch, ve Kardeş, 2017, s. 223-224). Zafer Şenocak'ın 1998 yılında yayınlanan otobiyografik romanı "Tehlikeli Akrabalık" multi-etnik kökenlere sahip Sascha Muhteschem'in kimlik sorunu ve kimlik arayışııı ele almaktadır. Sascha Muhteschem'in babası Türk, annesi ise 1930-1940'larda Türkiye'de sürgün hayatı yaşamış Alman Yahudisidir. Sascha'ya, anne ve babasının ölümünden 
sonra büyükbabasının günlükleri miras olarak kalmış, büyükbabası vasıtasıyla kendi geçmişini araştırmaya başlamıştır. $\mathrm{Bu}$ araştırma sürecinde birçok 'öteki' ve "ötekileştirmeyle" karşılaşılmıştır. Kimlik arayışındaki ana karakterin konu edildiği bu romandan hareketle bu çalışmada kimlik oluşturabilmek için bir 'öteki'ye ihtiyaç duyulduğu göz önünde bulundurularak ırksal, etnik, dinsel ve ekonomik nedenlerle ortaya çıkan 'öteki' ortaya konmaya çalışılmıştır.

\subsection{Etnik Köken Temelli ‘Öteki’}

Kimlik inşa süreçlerinde özellikle modernizm sonrası ortaya çıkan etnik temelli ulus devletler etkili olmuştur. Bu noktada etnik köken en sık ötekileştirme aracı olarak başvurulan ötekilerden biridir. Romanda da bu durum açıkça ortaya konulmaktadır. Etnik nedenlerle ortaya çıkan 'öteki' ele alındığında romanda köken bağlamında bir hiyerarşinin ortaya konduğu görülmektedir. Bu hiyerarşi Alman - Yahudi - Türk etnik kökenleri olarak sıralanmış ve romanda bu birçok kez hissettirilmiştir.

Romanın ana karakteri ve anlatıcısı Sascha Muhteschem, Türkiye'de sürgünde yaşayan Alman Yahudisi annesi tarafından Almanya'da dünyaya getirilmiştir. Dolayısıyla öteki ve ötekileştirme ilk olarak ailesinde başlamıştır. Anne, oğlunu Alman gibi yetiştirmek istemiş ve evde Türkçe konuşulmasını yasaklamıştır:

“Annem beni Almanya'da dünyaya getirmek istiyordu. Beni bir Alman yapmaya çok önem veriyordu. Bu yüzden ben doğduktan sonra evde artık Türkçe konuşulmaz oldu; oysa daha önce mutlaka ara sira konuşuluyor olmalıyd1." (Tehlikeli Akrabalık, s. 58).

Annesi kendi Yahudiliğini ve Sascha'nın babasının Türk olmasını yok sayarak oğlunun Alman olarak daha rahat bir yaşam süreceğini iddia etmektedir. "Annemi sorularımla sikıştırdığımda, bu önlemi bana farkl dünyaların arasında rahat bir yaşam sağlamak için aldığını söyledi." (A.g.e., s. 58). Bu cümleden yola çıkıldığında ulusal, etnik ve kültürel farklılıkları içerisinde bulunduran bir ülke olan Almanya'da, Alman gibi olmanın Türk veya Yahudi olmaktan daha avantajılı olduğu sonucu çıkmaktadır.

"Bir defasında Dahlem'de çok seçkin ve bakımlı bir evde oturan bir kadın bana, günümüzde Türklerin o zamanki Yahudilerden çok daha kötü olduklarını söylemişti. Yahudiler kendilerini Almanlıkla maskelemişlerdi, sanki Almanmış gibi yapmışlardı. Gerçi bu maskeleri düşürülmüştü. Ama bu onların sonuydu. Kadın bir süre düşündü, sonra Yahudiler ile Almanları nefretle karlşık bir sevginin birleştirmiş olduğunu söyledi. Ama Türkler ile Almanlar arasında yalnizca nefret vard." (A.g.e., s. 65-66).

Görüldüğü üzere etnik köken bakımından yapılan ‘öteki’ sıralamasında en kötüsünün Türkler olduğu vurgulanmaktadır. Yahudilerin Almanlaştığını ve bu nedenle karşılıklı bir sevginin oluştuğunu fakat Türklerin Yahudiler gibi Almanlaşmadıklarını ve bu nedenle bir nefret ilişkisinin bulunduğu "seçkin" bir Alman tarafından açıkça belirtilmektedir. İkinci Dünya Savaşı sırasında katledilen Yahudilerin utancını halen yaşayan Alman milleti, Yahudileri kendilerinden saymaya başladıktan sonra asıl 'öteki' konumuna ülkelerine çalışmak için gelen ve dönmeyen Türkleri koymuş görünmektedir. Sadece Almanlar değil, Yahudiler bile kendilerini Alman 'Biz'ine dâhil edebilmek amaciyla Türkleri ‘öteki’ olarak kodlamaktadır:

“Günümüzde kim Alman, kim değil sorusu sorulduğunda, Türklere bakllyyor. Alman olmanin sinirları, onlarda sinaniyor. Almanlıklarından emin olmak isteyen Yahudiler, aynada Türkleri keşfediyorlar." (A.g.e., s. 90).

Fakat Avrupa'daki ırkçılık akımlarıyla zirve yapan Yahudi düşmanlığının tamamıyla ortadan kaldırılamadığı, romanda Almanların "kendileri" gibi olmaya çalışan Yahudileri bir hastalık olarak gördükleri de gözden kaçmamaktadır:

"Bir Yahudi'nin tam bir Alman olmak için Yahudiliğinden ne zaman ve nasıl vazgeçtiği sorusu, Alman Yahudilerinin zihnini kuşaklar boyunca meşgul etmiştir. Ten ve saç renginin 
açılması, dilin ve inancın Almanlaşması, Yahudileri Mısır'dan getirdikleri Yahudi hastalığından kurtaramamıştı." (A.g.e., s. 89).

Öte yandan yıllarca Almanlar tarafindan ezilen ve 'öteki' olarak görülen Yahudiler merkez konumda olan yani ezen Almanların tarafina geçmek istemiş, asimile olmuş ve bundan dolayı ezenin özelliklerini alarak Türkleri ötekileştirmiştir:

“Annem stradan bir Türk'ü asla kabul etmezdi. Alman Yahudilerinin, yoksul ve geri kalmış Türklere karşı, hiç çekinmeden dile getirdikleri küstahlı ve aşağılama, asimilasyonlarının bir sonucuydu. Sadece asimile edenlerin perspektiflerini, yarglların ve önyargılarını tamamen benimseyen bir kişi asimile olmuştur. Oryantalistlerin çoğu Alman Yahudi'siydi. Doğu'ya sonsuz tiranlık, yazgıcıllk, değişmezlik ve 'öteki'lik atfettiler.” (A.g.e., s. 92).

Romanın geçtiği dönem-(Berlin Duvarı'nın yıkılışı sonrası) göz önüne alındığında Almanya'da Berlin Duvarının çöküşü ile birlikte göç ve iltica politikası değişmiştir. Eski Sovyetler Birliği ülkelerinden etnik köken bakımından Alman olan Rus ve Polonyalılar göç etmiş ve Alman vatandaşlığını almışlardır. Bu dönemde yine eski Yugoslavya'dan gelen iç savaş mültecileri de Almanya'ya giriş yapmıştır. Bu durumun ortaya çıkardığı tepkiler romanda da açıkça vurgulanmaktadır:

"Alman ulusal devletiydi bu. Ama duvart geri isteyenlerin sayısı da her geçen gün artıyordu. Değişimden sonra işsiz kalanları ya da siyasal ortama çabucak ayak uyduramayacak kadar katı olanları anlayabiliyordum." (A.g.e., s. 33).

Artan yabancı nüfusu ve işsizlik sayısı ile ırkçılık ve yabancı düşmanlığının da arttığı romanda öne çıkan bir diğer ötekileştirme ve 'öteki' motifidir:

“Ancak, duvarın yıkılışılla birlikte Berlin'de bazı şeyler hissedilir ölçüde değişti. Sanki duvarın ortadan kalkmasıyla birlikte, insanı bilinmeyen her türlü şeyden koruyan bir koruyucu kabuk dökülmüştü. En yakın köşenin arkasında pusu kuran bilinmeyen, insana, her türlü egzotik ülke insanının hayalinden daha yabancı ve tehditkâr görünür." (A.g.e., s. 127-128).

Duvarın yıkılışı aslında fiziki bir sınırın ortadan kaldırılması olsa da, insanların etraflarına çizdiği hayali duvar ile 'öteki' daha belirgin hale gelmiş ve bu kişiler Alman toplumunun dışında bırakılmıştır:

"Sanki duvarın yıkıllşı, eski düzenin çöküşü özgürleştirici bir işlev görmekle kalmamıştl; duvarın yokluğunda insanlar kendilerini açığa çıkmış hissediyorlardı. Kimlik, gizlenmişliğin bir aracı olmuştur. İnsan kökenini, yakınlıkları ve uzaklıkları belirlemek için, gözlerini 'öteki’lere dikiyor. Her yerde, duvarın yıkılışından sonra örülen görünmez duvarlara çarpılabilirdi." (A.g.e., s. 47).

Romanda insanların ötekileştirildiği vurgulanırken, oluşan ön yargı ve steryotipleştirmenin bu noktadaki rolüne vurgu yapılmaktadır. Özellikle yabancı nüfusunun en büyük kısmını oluşturan Türklerin aidiyet ve kimlik sorunları ile karşı karşıya kaldığı açıkça gösterilmektedir:

"Şimdi duvartn ylkıldiğı ve benim aidiyetimin sorulduğu yerde, her şey yeniden yükseliyor. Insan bastırdı̆̆ şeyi asla unutmuyor. Bastırılan şeyi anımsamak için kulağa yabancı gelen bir soyadının kodlanmast gibi, tek bir vesile yetiyor." (A.g.e., 129).

Her ulus devlette olduğu gibi Alman ulus devleti kendi "Biz" kimliğini oluşturma amacıyla etrafına bir sınır çizmiş ve yabancıları bu "Biz" kimliğinin dışında tutmuştur. Artan yabancı nüfusu ile Almanya'da 'öteki' olan kısmın fazla yer kapladığını bir okul sırası ile betimleyen Zafer Şenocak Almanya'da yaşayan toplumun 'Biz' ve 'öteki'ler' arasında ki çizgisini romanda şu şekilde açıklamaktadır: 
"Okulda aynı strada oturuyorduk; ta ki, günün birinde Karl ıvır zıvırımla—bununla defterlerimi ve kalemlerimi kastediyordu sırada hakkım olandan fazla yer kapladığımı iddia edinceye kadar. Tebeşirle sırayı tam orta olarak kabul ettiği bir yerden ikiye ayıran, dümdüz bir çizgi çekti. Artık ben kendi yarımda oturuyordum, o kendi yarısında. Cetvel kullanmadan böyle düz bir çizgiyi nasıl çizebildiğine şaşırmıştım. Ben bunu cetvelle bile yapamıyordum." (A.g.e., s. 102-103).

Kendi kimlik ve biz duygusunun oluşumu için toplumların kendilerinden farklı ve daha aşağıda gördüklerini ötekileştirmesi bilindik bir tanımdır. "Tehlikeli Akrabalık" romanında bu hem Sascha Muhteschem üzerinden, hem de Zafer Şenocak'ın kendi adı ile yazdığı monologda açıkça belirtilmektedir:

"Yazara kimliği sorulduğunda -ki bu çok yaygin bir sorudur, çünkü bu soruyu soran hemen hemen her zaman, kendi kimliğinden de emin değildir-yazar geriye yaslanır ve saymaya başlar." (A.g.e., s. 102).

Almanya'da 1 Ocak 2000 yılında yürürlüğe giren yeni vatandaşlık yasasına kadar "jus sanguinis" soy bağı ilkesi geçerli olmuştur. Bu yasayla bir çocuğa Alman babası veya Alman annesi varsa doğumda Alman vatandaşlığı alma hakkı tanınmıştır. Ayrıca yasal olarak Federal Almanya Cumhuriyetinde 15 yıl ikamet eden yabancılara Alman vatandaşlığına geçme hakkı tanınmış ve en az 8 yıl Almanya' da yaşayan ve en az altı yıl Almanya'da öğrenim gören 16 ve 23 yaş aralığındaki gençlere de Alman vatandaşlığına geçme hakkı verilmiştir (Ennigkeit, 2008, s. 95). Romanın başkarakteri Sascha Muhteschem bir "yasa boşluğu" sayesinde 18 yaşına bastıktan sonra babasının Türk vatandaşı olması ve Almanya'da yaşaması nedeniyle hak kazandığı Alman vatandaşlığına geçmiştir. Ancak bir Türk soyadına sahip olan Sascha, Alman vatandaşlığına geçmesine rağmen bir Alman olarak kabul edilmemiştir:

"Elbette, pasaportuma göre Almandım. Ama bu durum, sorunu daha da karmaşıklaştırıyordu. Çünkü benim gibi birisi, pasaportuna göre aslında kesinlikle Alman olamazdı. Almanlı̆̆ pasaportun olsa bile edinemezsin Alman olarak kabul edilmezsin." (A.g.e., s. 128).

Buradan da anlaşılacağı üzere kâğıt üzerinde Alman vatandaşı olan yabancı kökenliler yine Almanlar tarafından Alman olarak sayılmamakta ve Almanların aslında soy bağı ilkesini kendi zihinlerinde devam ettirdiklerini göstermektedir. Bu dönemde artan yabancı düşmanlığ ve Alman milliyetçiliği ile ırkçı eylemleri de romana yansıtan Zafer Şenocak, "Her ait olmayışın bir bedeli var" (A.g.e., s. 121) diyerek 'öteki' olmanın doğurabileceği kötü sonuçlara da dikkat çekmektedir.

Zafer Şenocak romanda kendi ülkesinden çalışmak için Almanya'ya gelen Türk vatandaşlarının aidiyet problemlerini ele alırken, 'öteki'nin ötekileşme ile karşı karşıya gelişini de konu edinmektedir. "Çünkü Almanya'da bir varoluş sorunu olan aidiyet sorununun çözümü, sadece ve sadece Alman Markı'ndan geçiyor" (A.g.e., s. 12) diyen yazar, çalışma amaciyla "bu ülkeye göç etmiş akıllı insanlar Alman pasaportu gibi değersiz şeylere değil, öncelikle Alman Markı'na sahip olmaya baklyorlar" (A.g.e., s. 12) diyerek Türklerin amaçlarının Alman toplumuna ait olmak veya kabul edilmek değil para kazanmak olduğunu belirtmektedir. Almanya'ya gelen birinci kuşak göçmenlerin amacinı ele alan yazar, dönmeyip Almanya'da kalan ve Almanya'da dünyaya gelen çocukların yaşadıkları sorunlara da değinmektedir: Zafer Şenocak "Insan çocukken yabancıllğg ve yabancilarl nasıl algılar? Annesi ya da babası dışındaki herkes yabancı değil midir?" (A.g.e., s. 105) diyerek Türklerin çocuk yaşta ötekileşme sorunu ile karşı karşıya geldiklerini ve bu nedenle bir aidiyet sorunu yaşadıklarını dile getirmektedir.

Almanya'ya göçün başladığı 60'lı yıllardan itibaren orada yaşayan Türkler artık kendilerini Almanya'da evinde hissetmeye başlamıştır. Romanda bu duygunun Almanlar tarafından hoş karşılanmadığı ve Almanların kendi koydukları sınırları aşmak isteyen 
yabancıları daha da ötekileştirerek onlara "biz" olunamayacağını hissettirdikleri ifade edilmektedir.

"Insan Almanya'da kendini ne denli evinde hissederse, Almanlara ne denli yakınlaşırsa, Almanların gözünde o denli yabancı oluyordu. Almanlar, kendi görüntülerini yansitan aynayı parçalama ĕ̌ilimindeydiler. Bir yabancı Almanı yansıtacak ölçüde yakınlaştığında, tehlikeli bir bölgeye girmiş oluyordu." (A.g.e., s. 106).

Romanda Almanlar, yabancılara Almanya'ya ait olmadıklarını göstermekte ve onlara ‘öteki’ olduklarının mesajını vermektedirler:

"Bu yarışma daha çok, yabancılara yabancılıklarını kabul etmeleri için yapılmış bir teklifti ve Almanya'da bir yabancı olduğunu algllamak istemeyen benim gibi insanlara yönelik de bir uyarlydı". (A.g.e., s. 106).

Almanya'da yaşayan Türk kökenli (yazarlar) Alman dilinde yazsalar dâhi Alman edebiyatına kabul edilmemektedir. Türk olmaları bunun için yeterli bir şart olup göçmen yazılarını içeren "Yabancılar Edebiyatı" kategorisinde yer almaktadırlar. Bu edebiyat türünün isim bakımından da bir ötekileştirme olduğu romanda belirtilmektedir:

"Veronika: Günümüzde Bir Aşk Üzerine adlı biricik yazınsal yapıtım, ansızın keşfedilip Yabancılar Edebiyatı denen tür altında sınıflandırıldiğında nasıl da şaşırmıştım. Bilimsel yazılarda adım artık Almancayı ustaca kullanan bir Türk yazar olarak geçiyordu." (A.g.e., s. 129).

Bunların yanında toplum veya grupların dışında bireylerin de etnik kökenleri nedeniyle ötekileştirildiği romanda etkili bir biçimde ele alınmaktadır. Sascha'nın eşi Türkleri olumsuz özellikler ile bağdaştıran bir Almandır:

"Hatta evden dişarı çıkarken televizyonu kapatmayı unuttuğum bile olurdu. Marie bunu "katlanılmaz” bulur, benim Türk genlerime atfettiği bir kabalık olarak görür.” (A.g.e., s. 49).

Romanda Sascha'ya ismini öğrenmeden "Sen sünnetli misin?” (A.g.e., s. 81) diye soran Alman Heinrich, Sascha'nın sahip olduğu Alman-kimliğinden önce Türk ve Müslüman kimliğini sorgulayarak ötekileştirmektedir. Ayrıca "Heinrich genç bir Türk kadınla arkadaştı. Bu kadını, despot babasından kurtardığı için gurur duyuyordu" (A.g.e., s. 82) ifadesi ile Heinrich kendisini yani bir Almanı kurtarıcı olarak görmekte ve Türk olan babasını olumsuz ifadelerle betimlemektedir.

Eserde, yabancılara yüklenen olumsuz özelliklerin yanı sıra Almanya'da fiziksel olarak bir Alman görüntüsünün ne kadar güvenilir olduğu da ele alınmaktadır:

"Belgelerini devletin bir görevlisine teslim etmek istemiyorlardl ve özel bir kişinin, özellikle de, düzgün giyimi, kısa sarı saçları, mavi gözleriyle, elden çıkarılacak malzemenin mutlak doğru alıcısıymış gibi görünen benim gibi nazik, konuyu iyi bilen genç bir adamın bu belgelerle ilgilenmesine açıkça seviniyorlardı.” (A.g.e., s. 65).

Yabancılara yabancı oldukları unutturulmamaya çalışılmakta ve bu hep bir şekilde hatırlatılmaktadır. "Bir gün bana Almanya'da Yabancı Olmak adında bir kitap hediye edildi. Arkadaşım Joseph-hepimiz ona Sepp derdik—"Bunu okumalısın, tam sana göre," diye yorumladı hediyesini." (A.g.e., s. 105). Sen "Biz"den değilsin mesajı barındıran bu hareket açıkça bir ötekileştirmeyi tasvir etmektedir.

Edebiyat alanında ötekileştirme ve 'öteki' bazen imgeler veya benzetmeler ile ifade edilmektedir. 'Öteki'ni” simgeleyen veya çağrıştıran objeler kullanılmakta ve böylelikle 'öteki' tasvir edilmektedir. Yazar, romanda Arap ve Türk yazarlardan bahsederken masalların yeniden başarı kazandığını ve bunları tercüme edecek "hayvanlara" gereksinim duyulduğunu belirtmektedir. 
"Bu metinlerde tercih edilen hayvanlar, develerin yanı sıra, özelikle eşeklerdi. Masallarda eşekler genellikle insanlardan daha kurnaz olduklart için her zaman bilgece bir söz söylüyorlardl. Alman kitlesine hitap edebilmek için uzun bir yoldan geldikleri hissediliyordu. Onları güdenler, mesleklerinin erbabıydl. Hayvanlarını Almanya ziyareti için çok iyi terbiye etmişlerdi. Eşeklerin hepsi de Almanca konuşuyordu, ama tuhaf bir Almancaydı bu; çünkü konuştukları şeyi, Almanca düşünmüyorlardı. Almanca eşeklerin düşünemeyeceği bir dildir. Ama onlar, bu dilde yazmak için bu dilde düşünmek gerekmeyişine örnek olarak gösterildiler. Hatta bu dil, bu dilde düşünme yeteneğine sahip olduğunda asla bulunamayacak sözcüklerle zenginleştirilebilirdi. " (A.g.e., s. 130-131). Almanya'da yaşayan Türklerin de çok uzaklardan geldikleri ve kayda değer bir kısmının Almancayı Almanlar kadar düzgün konuşamadıkları göz önünde bulundurulunca "Eşek imgesi ile Türkler mi tasvir ediliyor?" sorusu insanın aklına ister istemez takılmaktadır.

Almanların yanı sıra Türklerin de Almanları ötekileştirdiği ve kendi oluşturdukları "Biz" grubuna dâhil etmedikleri romanda anlatılmakta ve ötekileştirmenin diğer yüzü ortaya konmaktadir:

"Almanlar yabancıdır", "Biz onları anlamıyoruz", "Bizi ayıran çok şey var" diyen romandaki Türk karakterler kendilerini olumlu özelliklerle tasvir etmekte, örneğin; "uslu, masum, utangaç" fakat Almanları "egoist insanlar", "iğrenç", "hastalar", "domuzlar", "haram et", "beceriksizler", "korkaklar sürüsü", "namus, ahlak ve utanma duygusunu bizden ögrenebilirsiniz, sizi kıçı boklular" (A.g.e., s. 88-100) gibi olumsuz ifadelerle betimlemektedir. Buradan da görüldügü gibi ters bir ötekileştirme yapılmakta ve azınlıkta olan grubun merkez konumda olan Almanları ötekileştirdiği görülmektedir.

Tüm ötekileştirme nedenlerini barındıran aşağıdaki alıntıda 'öteki' konumunda olan Türkler, bir Alman tarafından yasadışı işler ile uğraşan, ahlaksız, nefret dolu ve yobaz olarak betimlenmektedir. Türkler ekonomik olarak kötü durumda, yönetilmesi gereken bir millet olarak tasvir edilmektedir:

“Türkler niye mi geldiler Almanya'ya: Çalışmak ve para kazanmak için, uyuşturucu kaçakçıllı̆̆ yapmak için, bir manav dükkânı açmak "için, Almanlara yemek pişirmeyi ögretmek için, orospuluk yapmak için, soğuk iklime karşın kan davası gütmek için, Kuran'ı ezberlemek için, bir kadını unutmak için, yoksul Türk halkına bir futbol antrenörü, bir Führer bulmak için..." (A.g.e., s. 124).

\subsection{Medeniyet Temelli 'Öteki'}

$\mathrm{Bu}$ çalışmanın diğer bir bakış açısı medeniyet temelli ötekileştirmedir. Roman karakterlerinin sözleri üzerinden Batı üstün ve ideal medeniyet, Doğu ise uygarlıktan uzak, geri kalmış olarak tasvir edilmektedir.

Örneğin, Marie'nin Talat Paşa hakkında yaptı̆̆ 1 araştırma nedeniyle "Talat Paşa hakkında yeni bir şeyler var mı içinde? Karısı falan hakkında? Yok değil mi? Kaç karısı vardı ki?" (A.g.e., s. 15) sözlerine Sascha, "Yine oryantalizm yapmak zorunda misın? Iç̧indeki bu nefretle, bu insan hakkında nasıl sürükleyici bir belgesel film çekebilirsin?" (A.g.e., s. 15) diye karşılık vermiş ve devamında Batı'nın Doğu hakkındaki basmakalıp ön yargıları ile ortaya çıkan nefretlerini açıkça ortaya koymuştur. Bu noktada "Benim bakış açım bana yetiyor" (A.g.e., s. 16) diyen Marie ise tek taraflı düşünen, ön yargıları ile bir fikir oluşturan Avrupa'yı temsil etmektedir. Ayrıca Batı ve Doğu'nun farklı dinleri nedeniyle ayrı görüldüğünü ve Doğu'nun Müslüman olmasından dolayı da ötekileştirildiği ele alınmaktadır:

"Kadim bir Doğulu halk olan Ermeniler, sirf Müslüman bir çevrede yaşayan Hıristiyanlar oldukları için, kurgusal bir biçimde Batıll yapıldılar. Buna karşıllk, yüzleri bölgedeki tüm öteki halklardan daha Batı'ya dönük olan Türkler, Müslüman oldukları için, Avrupalılar tarafindan asla Batılı olarak kabul edilmiyorlar." (A.g.e., s. 16). 
Avrupalıların üstün bir medeniyet olarak görüldüğü “Avrupalı olmak istiyorsanız, işkenceyi ortadan kaldırmalısınız” (A.g.e., s. 16) gibi ifadelerle vurgulanırken, Doğu'nun barbar ve insan haklarının olmadığı bir yer olarak kabullenildiği anlaşılmaktadır. Bu konuyu farklı bir bakış açısı ile ele alan Sascha karakteri ile birlikte Zafer Şenocak:

“Fransızlar, Cezayir'de işkence ve katliam yaparken, Avrupalı değil miydiler? Ya dünyanın yarısını yă̆malayan Ingilizler? Bu yüzden onlar Avrupa Parlamentosu'ndan ya da Avrupa Birliği'nden dışlandılar mi? Siz Avrupalılar hileli bir oyun oynuyorsunuz, ikiyüzlüsünüz. Beyaz adam hep ikiyüzlüdür" (A.g.e., s. 16) diyerek Avrupa'nın aslında kendini tasvir ettiği gibi olmadığını ve onunda insan haklarını ihlal ettiğini açıklamaktadır.

Türkiye Cumhuriyetinin kuruluşundan sonra Türklerin Doğu'ya sırtını dönerek Batılılaşmak istemesi ayrıca medeniyet temelli ötekileştirme açısından romanda karşımıza çıkan bir başka unsurdur. Doğu geri kalmışlığı simgelemektedir. Türkiye doğulu köklerinden koparak Batılılaşacak ve modern bir devlet olacaktır:

“İstanbul'daki sürgün Alman cemaati hızla genişledi. Çok sayıda kişi bu şehre geldi. Ankara'dakiler ellerini ovuşturuyordu. Hükümet, geri kalmış Türkiye'yi kısa sürede modernleştirmek istiyordu. Türkiye bir Avrupa ülkesi olacak, Doğulu köklerinden kopacaktı." (A.g.e., s. 54-55).

Atatürk'ün reformları Türkleri "Avrupalılaştıramak” için yeterli olmamış ve Türkler Doğulu kalmaya devam etmişlerdir.

"Ulusal să̆llğın gerekliliğine inanıyorum. Ona göre, Türklerin oranının yüksek olması, Avrupa uluslarının savunma gücünü zayıflattyor. Türkler Atatürk'ün reformlarlyla sadece Avrupalı bir kılı̆̆a büründüler. Ne var ki maskeleri, onların karakterini Asyalı-Doğulu yönünü gizleyemiyor." (A.g.e., s. 86).

Avrupalıları yine Doğululardan üstün gösteren bir diğer ifade ise "Göçmenlerin $A B D$ 'de doğan çocukları daha iriydi, daha açı tenliydi ve beyin kapasiteleri daha büyüktü. Avrupalı tipine daha yakindllar. Daha kolay entegre olacak gibiydiler" (A.g.e., s. 84) dir. Burada Avrupalı tipi daha zeki olarak tarif edilmektedir.

\subsection{Ekonomik Temelli 'Öteki'}

Ötekileştirmenin bir diğer nedeni, ekonomik (kimilerine göre ise sınıfsal) temellidir. Ekonomik açıdan ötekileştirmeye bakılacak olursa yoksulun ve böylelikle daha az güce sahip olanın ötekileştirildiği durumların da eserde mevcut olduğu görülmektedir. Kapitalist toplumlarda para çok önemli bir yere sahip olup, güç ve medeniyet anlamlarını taşımaktadır. Bu doğrultuda romanda da taşra veya kenar mahallelerde yaşayan insanlar merkez konumunda olan Batılı insanın seviyesinin altına yerleştirilip olumsuz ve kötü özellikleri ön plana çıkarılarak 'öteki'liği belirginleştirilmektedir:

“Kreuzberg'de bir ev arayalım, böylece sen de kendini vatanında hissedersin, dedi sinsi sinsi gülümseyerek. Ayrıca Kreuzberg'teki evler biraz perişan ve büyüktür" (A.g.e., s. 21) ile Kreuzberg'de çoğunluğunun Türklerden oluşan insanların perişan ve kötü evlerde yaşadıkları söylenmektedir. Burada bilhassa Türklerin kendi vatanlarında da kötü şartlarda yaşadıkları söylenmek istenmiş ve Türkiye dâhil tüm Türk toplumu olumsuz özellikler ile ötekileştirilmiştir.

Ekonomik açıdan düşünüldüğünde göçmen işçiler Almanya'ya para kazanmak amacıyla giden emek göçmenleridir. Almanya sınırlarının dışından gelmiş olmaları, yabancı yani 'öteki' olmaları için yeterli bir unsurdur. Fakat çektikleri ekonomik sıkıntılar ve Almanların ülkesine onların paralarını kazanmak için gelmiş olmaları da öteki olduklarını perçinleyen önemli bir özelliktir. Bu durum romanda da açıkça ortaya konulmaktadır: 
“İlk misafir işçileri- Italya ve Yunanistan'dan gelmişlerdi-Dachau'daki toplama kampının çürük barakalarında barındırmışlardı. Orada kendi başlarınaydılar. Durumları hiç de fena değildi. Çünkü ceplerini sağlam Alman marklarıyla doldurmaya başlamışlardı. Almanya onlara para ve cemaatten başka daha ne versindi ki?" (A.g.e., s. 125).

\subsection{Dinsel Temelli "Öteki”}

Etnik, medeniyet ve ekonomik temelli ötekileştirmenin yanı sıra diğer önemli bir ötekileştirme nedeni ise dindir. Ulus devlet kavramının ortaya çıkışından önce insanlar ötekileştirmeyi dinler üzerinden gerçekleştirmekteydi. Dinsel ötekileştirmede de aynı etnik ötekileştirmede olduğu gibi diğer dinleri küçümseme yer almaktadır. Müslümanların Batının gelişmişliğini yakalama çabasında olmamaları, geleneklerine ve dinlerine bağlı olmaları ve geleneklerini korumaları, ötekileştirilmelerine yeterli sebeplerdir. $\mathrm{Bu}$ bağlamda, Batılılar Doğuluları aşağılarken dini temelde ötekileştirme özellikle söz konusu olmaktadır. Bunun tam tersi olarak Doğu toplumlarının Batı toplumlarını ötekileştirdiği de görülmektedir.

"Tehlikeli Akrabalık" romanında Osmanlı İmparatorluğunda Müslüman ve Yahudi kesiminin huzurla bir arada yaşadıkları anlatılmaktadır. Fakat "Hıristiyanlar ise onlara, Avrupa'da Hiristiyanlıkla savaşan İslam'in müttefikleri gözüyle bakıyordu. Milliyetçilik filizlenirken, bu duygular da güçlendi. Yahudiler ve Türkler dönüşümlü olarak, Hiristiyan Yunanlıların ve Ermenilerin düşman imgesi oldular" (A.g.e., s. 56).

Ermenilerin "sırf Müslüman bir çevrede yaşayan Hıristiyan oldukları için (A.g.e., s. 16) "ideal" Batıya dâhil edildikleri fakat Batıya daha yakın olmasına rağmen Türklerin "Müslüman oldukları için, Avrupalılar tarafindan asla Batılı olarak kabul edilmemesi" (A.g.e., s. 16) yine Batının din temelli motiflerle Müslüman halkı ötekileştirdiğinin romanda karşımıza çıkan bir diğer işaretidir.

İslam dinini kötü özellikler ile betimleyen diğer bir kısımda ise Müslümanların pis insanlar olduğu söylenmektedir:

"İslam, yaşamları boyunca sadece ayak kokusu, sakal ve sperm üreten erkekler için mükemmel bir inanç cemaati sunuyormuş gibi görünüyor. Bu inancın en kötü yanı, pislikten başka bir şeyin bulunmadığı yerde, temizlik yanılsaması uyandırıyor oluşu”. (A.g.e., s. 110).

Romanda Almanların, göçmenlerin sadece dillerini, yasalarını veya alışkanlıklarını benimsemelerini değil aynı zamanda dinlerini de benimsemelerini istedikleri belirtilmektedir: "Almanya'ya gelmemizden sonraki ilk kış mevsimiydi. Karl bizim eve gelmişti. "Senin Noel ağacın nerede?" diye sordu, oturma odasına girdiğinde. Anneme, bizim Noel ăgacımizın nerede olduğunu sordum. Annem de babama, bizim Noel ă̆acımızın nerede olduğunu sordu. Babam da sevgili Allaha Noel ağacını sordu. Allah'ın gücüne gitti”. (A.g.e., s. 103-104).

11 Eylül olaylarından sonra artan Müslüman eşittir terörist yargısı romana da yansımıştır:

"Yazım üç gün sonra tam sayfalık bir röportaj halinde yayımlandl. "Benim koyduğum "Cumaları namaza, pazarları masa tenisine" başlı̆̆ kullanılmamıştı. Bunun yerine, manşetten "Müslümanlar Mahallelerimizde Tehdit mi Oluşturuyor?” başlı̆̆ verilmişti. Hayretle gördüm ki yazıma resim olarak, Oranienburg Caddesi'ndeki restore edilen sinagogun altın kubbesi seçilmişti”. (A.g.e., s. 112).

Burada cami ile alakalı çok bir bilgiye sahip olmayan ve ön yargı ile yaklaşan gazete ve onun temsil ettiği görüş Müslümanları bir tehdit olarak görmekte/göstermekte ve habere cami yerine bir sinagog resmi koymaktadır.

Yazar dinsel temelli ötekileştirmeyi Müslümanların açısından da vermektedir. Müslümanlar da diğer dinlere mensup kişileri ötekileştirmektedir. Yani karşılıklı bir ötekileştirme söz konusudur: 
"Girişte duran bildirilerden birinde "Birlikte Allah'ın davasını güdelim, gâvurun davasında güdülmeyelim” sloganı yazıllydı." (A.g.e., s. 110).

Ötekileştirmenin nasıl ortaya çıktığını "Sonra yabancı öğretmenler geldi-çok gezmiş birine yabancı denirdi buralarda - ve onlara adlar taktllar; Türklere Türk, Kürtlere Kürt, Alevilere Alevi adları." (A.g.e., s. 76) ve bir “ulus”un parçası olma düşüncesiyle o zamana kadar birbirleri ile yakın olan, "Hiçbiri diğerinin adını duymak istemiyordu. Aileler arasında bir çatlak oluştu, çocuklar birbirine yabancı olarak yetişti” (A.g.e., s. 76) fakat farklı uluslara ve dinlere mensup olan kişiler arasında nasıl bir ayrışma ortaya çıktı̆̆ını anlatan yazar bunu hem etnik köken hem de din üzerinden aktarmıştır.

"Bu sırada Türkler, Hiristiyan oldukları için Yunanlı saylldılar; Yunanlılar da, Müslüman oldukları için Türk sayıldılar. Birbirlerine yabancı gözüyle baktılar. Hiç gezip dolaşmamış komşularına yabancı dediler.” (A.g.e., s. 76).

\section{Sonuç}

Zafer Şenocak "Tehlikeli Akrabalık” romanında ötekileştirmelere hem ana izlek olarak hem de satır aralarında değinmiştir. Romanda ele alınan 'öteki' ve ötekileştirme etnik köken, medeniyet, ekonomik ve dinsel temelli nedenlerle karşımıza çıkmaktadır.

Ulus devletlerin ortaya çıkışı ve devamında etnik bilincin uyanmasıyla etnik köken en sık ötekileştirme aracı olarak başvurulan 'öteki'lerden biri haline gelmiştir. Romanda da bu durum ana karakterin kimlik arayışı sürecinde işlenen ana temalardan biridir. Etnik nedenlerle ortaya çıkan 'öteki' ve ötekileştirme ele alındığında romanda köken bağlamında bir hiyerarşinin ortaya konduğu görülmektedir. Bu hiyerarşi sırasıyla Alman - Yahudi - Türk etnik kökenleri şeklinde verilmiş ve romanda okura birçok kez hissettirilmiştir.

Romanda karşımıza çıkan bir başka ötekileştirme boyutu ise medeniyet temelli ötekileştirmedir. Ağırlıklı olarak oryantalist bakış açısı romanda genellikle Alman karakterler tarafından dile getirilmektedir. Söz konusu karakterlerin, Batıyı üstün ve ideal medeniyet olarak, Doğuyu ise uygar olmayan, geri kalmış bir medeniyet olarak tasvir ettikleri görülmektedir.

Ötekileştirmenin bir diğer nedeni, ekonomik temellidir. Ekonomik açıdan ötekileştirme, yoksulun ve dolayısıyla da daha az güce sahip olanın ötekileştirilmesi şeklinde romanda karşımıza çıkmaktadır. Kapitalist toplumlarda para çok önemli bir yere sahip olup, güç ve medeniyet anlamlarını taşımaktadır. Romanda da taşra veya kenar mahallelerde yaşayan insanlar, merkezde yaşayan ve üstün olan Batılı insan karşısında daha aşağı konuma yerleştirilmiş ve genellikle olumsuz özellikleri ile ön plana çıkartılmışlardır.

Etnik, medeniyet ve ekonomik temelli ötekileştirmenin yanı sıra diğer önemli bir ötekileştirme nedeni ise dindir. Tarihin çok eski dönemlerinden beri var olduğu düşünülen din temelli ötekileştirmede de aynı etnik ötekileştirmede olduğu gibi diğer dinleri küçümseme yer almaktadır. Oryantalist ve Batı merkezli bakış açısının şekillendirdiği; Hristiyanlık dışındaki dinlere tepeden bakma anlayışının yansımaları "Tehlikeli Akrabalık" romanında da görülmektedir. $\mathrm{Bu}$ bağlamda, Batılılar Doğuluları aşağılarken özellikle dini temelde ötekileştirme söz konusu olmaktadır. Bunun tam tersi olarak eserde Doğulu Türklerin de Batılıları dinsel temelli ötekileştirdiği görülmektedir.

\section{Kaynakça}

Abels, H. (2010). Identität. Wiesbaden: Springer-Verlag.

Akpınar, S. ve Şahin, B. (2017). Orhan Pamuk Romanlarında "Öteki. Avrasya Uluslararası Araştırmalar Dergisi, 5(11), 330-344.

Assmann, A. (1994). Zum Problem der Identität aus kulturwissenschaftlicher Sicht. Leviathan, 21(2), 238-253. 
Ennigkeit, S. (2008). Gelungene Integration?: Zuwanderung und Integrationspolitik in Deutschland und den Niederlanden. Karlsruhe: Arnold-Bergstraesser-Institut.

Er, M., Koçak, S., Hertsch, M. F., \& Kardeş, B. (2017). Kulturelle Leitbilder in der Literatur von Zafer Şenocak aus ausgewählter Literatur durch den Präsenzworkshop mit Zafer Şenocak. Diyalog Interkulturelle Zeitschrift Für Germanistik, 5(2), 222-234.

Habermas, J. (2015). Öteki Olmak “Öteki”yle Yaşamak, Siyaset Kuramı Yazıları. İstanbul: Yap1 Kredi Yayınları.

Heidegger, M. (2006). Identität und Differenz (GA 11). Frankfurt a. M.: Klostermann.

Kalkan, H. K. (2017). Konuk İşçi Edebiyatından Kültürler Arası Edebiyata Evrilen Adlandırma Sürecine Tarihsel Bir Bakış. Schriften zur Sprache und Literatur (pp.190-198), Londa: IJOPEC.

Kalkan, H. K. (2018). Infragestellung der Identität durch die Gesellschaft in Zafer Şenocaks "Gefährliche Verwandschaft". ZfWT, 10(1), 65-73.

Kimlik (t.y.). Türk Dil Kurumu Sözlükleri. https://sozluk.gov.tr (Erişim tarihi: 22.05.2020).

Kurtoğlu Zorlu, Ö. (2015). Türkçe ve İngilizce Atasözlerinde "Ötekilik". International Journal of Social Sciences and Education Research, 4(3), 483-500.

Öteki (t.y.). Türk Dil Kurumu Sözlükleri. https://sozluk.gov.tr (Erişim tarihi: 25.05.2020).

Öz, M. (2018). Değirmen Adlı Öyküde Ötekileştir(İl)me İzleği. Yeni Türk Edebiyatı Araştırmalart, 20(20), 127-138.

Perk, D. (2019). Osman Engin'in "Deutschland Allein zu Haus" ve Hatice Akyün'ün "Einmal Hans mit Scharfer Soße" Eserlerinde Kalıp Yargılar. Ankara Üniversitesi Dil ve TarihCoğrafya Fakültesi Dergisi, 59(2), 758-771.

Said, E. (1978). Orientalism. London: Penguin Books.

Staszak, J. F. (2008). Other/Otherness. http://www.unige.ch/sciencessociete/geo/files/3214/4464/7634/OtherOtherness.pdf_(Erişim tarihi: 15.05.2020).

Supper, S. (1999). Minderheiten und Identität in einer multikulturellen Gesellschaft. Wiesbaden: Springer-Verlag

Şengül, A. (2007). Edebiyatta Ötekilik Meselesi ve Türk Edebiyatında 'Öteki'. Karadeniz Araştırmaları, (15), 97-116.

Şenocak, Z. (2006). Tehlikeli Akrabalık. Istanbul: Alef Yayınları.

Uygur, N.(2016). Başka-Sevgisi. İstanbul: Yapı Kredi.

\section{ETIKK ve BIILIMSEL İLKELER SORUMLULUK BEYANI}

$\mathrm{Bu}$ çalışmanın tüm hazırlanma süreçlerinde etik kurallara ve bilimsel atıf gösterme ilkelerine riayet edildiğini yazar(lar) beyan eder. Aksi bir durumun tespiti halinde Afyon Kocatepe Üniversitesi Sosyal Bilimler Dergisi'nin hiçbir sorumluluğu olmayıp, tüm sorumluluk makale yazarlarına aittir.

\section{ARAȘTIRMACILARIN MAKALEYE KATKI ORANI BEYANI}

1. yazar katkı oranı : $\% 70$

2. yazar katkı oranı : \% 30 